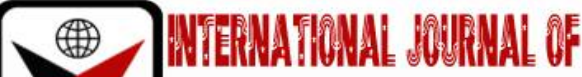

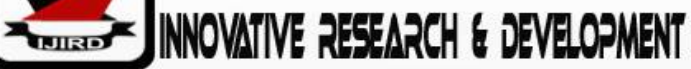

ISSN 2278 - 0211 (Online)

\section{Investigation of Physical Characteristics of Crude Oil Polluted and Non-Polluted Alluvial Soils in Niger Delta, Nigeria}

\author{
\begin{tabular}{c} 
Opene G. A. \\
\hline Student, Department of Soil Science, Federal University of Technology, Imo State, Nigeria
\end{tabular}
}

\begin{abstract}
:
We investigated the physical properties of soils affected by crude oil pollution, comparing it with non-polluted sites. Target sampling guided choice of sampling sites. In each site, a soil profile was dug, described and sampled using FAO procedure. Routine laboratory analysis was conducted on soil samples. Soil data were statistically analyzed using T-test and level of significance determined at 5\% level of probability. There was significant difference among particle size fractions at 5\% level of probability. Soil samples differed in the distribution of course and fine sands. Silt ranged from 144.6 to $406.6 \mathrm{~g} / \mathrm{kg}$ in crude oil polluted soils while 120.2 to $425.3 \mathrm{gkg}^{-1}$ in non-polluted soils. Clay varied from 102.2 to $573.9 \mathrm{gkg}^{-1}$ in polluted site and 81.1 to $511.3 \mathrm{gkg}^{-1}$ in non-polluted soils. Bulk density ranged from 1.43 to $1.55 \mathrm{mgm}^{-3}$ (polluted) and 1.27 to $1,141 \mathrm{mgm}^{-3}$ (non-polluted) sites. Permeability values were higher in non-polluted soils (0.18 to $3.45 \mathrm{~cm} \mathrm{hr}^{-1}$ ) then in polluted soils (-0.04 to $\left.1.89 \mathrm{~cm} \mathrm{hr}^{-1}\right)$.
\end{abstract}

Keywords: Alluvial soils, land use, pollution, Nigeria

\section{Introduction}

Most alluvial deposits are wetland soils whose development and properties are strongly influenced by temporary or permanent saturation at epipedons (Akamigbo, 2001). Land use of an area is excessively influenced by the existing ecological condition which in turn is a product of patterns of use depending on the kind and level of technology which is available to the people.

In spite of the alluvial deposit's potentials, agricultural development in Niger Delta area has remained insignificant due to paucity of information on soil infertility problems, insufficient technical information and poor soil management practices coupled with greater interest in non-agricultural activities including crude oil exploration and exploitation. However, heavy discharge of industrial waste products, gas flaring, pipeline leakages, and bunkering among others in the area by oil and gas industries. The situation is worsened by presence of other incredible oil-related economic activities which have resulted to the release of toxic waste materials consisting of heavy metals and organic contaminants into the soils and water bodies in the area. Movement of spilled oil into soil pores displaces soil oxygen thereby creating anaerobic conditions which reduces useful soil bacteria (Lilenfen et al, 2004). In addition to this, the weight of spilled oil on soils leads to increased compaction and bulk density of soils which negatively affects root penetration, root ramification and seedling emergence in affected sites.

\section{Materials and Method}

\subsection{Location}

The study was conducted at spilled and nonspilled sites of Ogba/Egbema/Ndoni area of Rivers State, Nigeria located between latitudes $05^{0} 2^{1} \mathrm{~N}$ to $05^{0} 30^{1} \mathrm{~N}$ and longitude $06^{0} 3^{1} \mathrm{E}$ to $06^{0} 42^{1} \mathrm{E}$. Ogba/Egbema/Ndoni Local Government Area (ONELGA) is the extreme north western fringe of River State, Nigeria. Ogba/Egbema/Ndoni lies in the humid tropical climate controlled by the southwest moisture laden and northwestern dry cold winds resulting to rainy and dry/harmathan seasons respectively. The annual rainfall ranges from $2540 \mathrm{~mm}$ to $4520 \mathrm{~mm}$ with June, July and September being wettest months every year. Relative humidity is very high especially during rainy season. Mean minimum and maximum annual temperature is $24-26 \mathrm{C}$ and $30-32 \mathrm{C}$.

Soils are formed by the accumulation of sedimentary deposits from main rivers of the area (Horsfall and Spiff, 2001). The common geomorphic surfaces in the area are levee crest, levee slope, complex of levee crest, mudflat terrace and back swamp. The area has mangrove swamp vegetation in the south while rainforest in the northern fringes. Main socio-economic activities in the area are fishing, hunting, lumbering, small scale arable crop production in addition to commercial exploitation of crude oil. 


\subsection{Field Study}

A target soil survey method was adopted in the study. Two land units: crude oil polluted and non-polluted sites were identified and sampled in each site. On each land unit, a soil profile was sunk and delineated into generic horizons. Soil profiles were dug, describes and sampled according to FAO (2006) procedures. Each soil profile was georeferenced using hand-held Global Positioning System (GPS) receiver. Soil samples were stored in polybags for laboratory analysis. Soil samples were air-dried and sieved using $2-\mathrm{mm}$ sieve. Core samples were also collected from soil profiles for bulk density determinations.

\subsection{Laboratory Analysis}

Particle Size Analysis was determined using the hydrometer method as cited by Gee and Or, (2002) and the soil textural class were determined using the textural triangle. Bulk Density was determined by the use of Core method as described by Blake and Hartge (1986). Total Porosity was calculated through mathematical expression of the relationship between bulk density and average particle density. Permeability was determined as the amount of water that moves downward through the saturated soil, while comparing the result with existing standards as described by Carter (1993).

\section{Data Analysis}

\subsection{Results and Discussion}

Coarse sand (CS) varied significantly ( $\mathrm{P} \leq 0.05)$ among locations (Table 1). Least value of coarse sand was found in $113.7 \mathrm{~g} \mathrm{~kg}^{-1}$ (Agwe) while maximum value of $284.0 \mathrm{~g} \mathrm{~kg}^{-1}$ was recorded in (Obagi) (Table 1). Fine sand (FS) differed significantly ( $\mathrm{P}=0.05)$ among locations, with $196.6 \mathrm{~g} \mathrm{~kg}^{-1}$ (minimum) and $378.5 \mathrm{~g} \mathrm{~kg}^{-1}$ (maximum) in Ebocha and Idu, respectively. Values of total sand (TS) ranged from $332.0 \mathrm{~g} \mathrm{~kg}^{-1}$ (minimum) to $636.6 \mathrm{~g} \mathrm{~kg}^{-1}$ (maximum) of Ebocha and Idu respectively. Soil samples differed in trend in their compositions of coarse sand and fine sand. Peter and Onweremadu (2015) reported similar value of total sand in Ogoni land.

Silt content ranged from $144.6 \mathrm{~g} \mathrm{~kg}^{-1}$ (minimum) at Ebocha to $417.4 \mathrm{gkg}^{-1}$ (maximum) of Obiozimini (Table 1) and these values reveals significant differences at less than 5\% level of mobility. Obi (2003) reported silt values of 60 to $386 \mathrm{~g}$ $\mathrm{kg}^{-1}$ soils of a similar environment. Clay values $\left(\mathrm{g} \mathrm{x} \mathrm{kg}^{-1}\right)$ varied from 81.1 to $513.3 \mathrm{~g} \mathrm{~kg}^{-2}$ and these differences were significant at $\mathrm{P} \leq 0.05$ least value of $81.1 \mathrm{~g} \mathrm{~kg}^{-1}$ was obtained at Utuechi while maximum value of $513.3 \mathrm{~g} \mathrm{~kg}^{-1} \mathrm{was}$ recorded at Ebocha (Table 1). Silt clay ratio ranged from 0.47 to 4.02 (Table 1). These ratios show that soils from Ebocha, Agwe, Obagi and Aggah are relatively old and highly weathered while the rest are young soils. Soil textural classes ranged from sandy loam, sandy clay loam, loam, clay loam and sandy clay. These textures vary and this were reported that deltaic soil change with location resulting to a variety of textural classes (Obi 2003).

Distribution of total sand differed from similar studies along Qua Iboe, Obio Akpa, Enyong Creek and Imo river where total sand values were 880, 906, 420 and 822. $\mathrm{kg}^{-1}$ (Ogban et al, 2011) in wetland soils of Akwa Ibom State, Nigeria. Differences in sandiness and indeed other particle size fractions could be attributed to local geology and degree of weathering Ogban et al (2011) as well as land use type (Onweremadu et al, 2011). Other particles size fractions of silt and clay varied between studied area and results from other scholars (Ogban et al, 2011). Soil particles sizes influence infiltration with sand having normal range of $2-25 \mathrm{~cm} \mathrm{hrs}^{\mathrm{s}}$ while other soil textures of sandy loam, loam silt clay and clay have 1-8, $0.1-2,0.2-1.5,0.03-0.5$ and $0.01-0.8 \mathrm{~cm} \mathrm{hr}^{-1}$ as normal infiltration rates (Landon 1991). Soil textures relates to soil structure and hydraulic conductivity locations such as Isukwa, Obagi, Obrikom and Omoku are dominated by coarse sands over fine sand implying preponderance of single grains and hydraulic conductivity of greater than $50 \mathrm{~cm} \mathrm{hr}^{-1}$ while fine sand creates medium crumb and single grain with hydraulic conductivity ranging from $12-25 \mathrm{~cm} \mathrm{hr}^{-1}$ (Landon, 1991)

\subsection{Effect of Crude oil Pollution on Soil Texture}

There were significant $(\mathrm{P} \leq 0.05)$ differences in particle size fractions between crude oil polluted and nonpolluted soils (Table 1). However, there were no regular trend among sand-sized fractions especially coarse sands. Highest value of coarse sand $\left(284.0 \mathrm{~g} \mathrm{~kg}^{-1}\right)$ was recorded in non-polluted soils of Obagi $\left(275.2 \mathrm{~g} \mathrm{~kg}^{-1}\right)$ and non-oil polluted soil of Omoku $\left(274.4 \mathrm{~g} \mathrm{~kg}^{-1}\right)$. Obi (2003) reported soil textures of deltaic areas vary in response to nature of sediments from which they are derived. However, a study conducted along PPMC Warri-Kaduna crude oil pipeline spill site near Effurun in Warri, Delta State, Abosede (2013) reported that there was no significant influence of crude oil a sand particle except when depth of sampling was considered. Similar trend was observed in clay size fraction (Marinecu, 2011) who observed no difference between polluted and non-polluted soils in silt and clay distribution.

Silt content ranged from $144.6 \mathrm{~g} \mathrm{~kg}^{-1}$ to $406.6 \mathrm{~g} \mathrm{~kg}^{-1}$ in crude oil polluted soils of the thirteen locations. Values of $120.2 \mathrm{~g} \mathrm{~kg}^{-1}$ (minimum) and $425.3 \mathrm{~g} \mathrm{~kg}^{-1}$ (maximum) were obtained at nonpolluted soils of Ebocha and Utuechi, respectively. Although there were significant differences ( $\mathrm{P} \leq 0.05)$, it did not show a defined trend (Table 3 ). In line with earlier arguments, crude oil pollution may not be the source of variation instead nature of lithological materials (sediments) from where soils are found plus land use history. Soil particle is an inherent property of soil which may not vary especially when soils were derived from a homogenous parent material over a period of similar land use practices. But sand sized fractions dominated other particle size fractions in studies conducted in Ugboroda community in the Niger Delta region of Nigeria (Oyem and Oyem, 2013).

\subsection{Bulk Density and Permeability Characteristics of Location}

Significant difference ( $\mathrm{P} \leq 0.05)$ was recorded among soils of the 13 locations (Table 2). Values ranged from $1.38 \mathrm{mgm}^{-3}$ (minimum) to $1.48 \mathrm{mgm}-3 \mathrm{~m}^{-3}$ (maximum) at Idu and Ebocha, respectively. These results contrasted with the 
findings of Oyem and Oyem (2013) who obtained a range of $1.27 \mathrm{mg} \mathrm{m}$ to $1.31 \mathrm{Mg} \mathrm{m}^{3}$ in crude oil-spilled sites at Ugborodo community. When crude oil spills, it occupies more spaces thereby increasing weight of soils which will invariably increase bulk density of affected soils. According to Landon (1991) soil bulk densities ranging from 1.1 t0 $^{1.4 \mathrm{Mgm}^{-3}} \mathrm{indicates}$ uncultivated and compacted soils while values ranging from 1.6 to $1.8 \mathrm{MG} \mathrm{m}^{-3}$ show compaction, which may restrict root movement and development. Comparing crude oil polluted and non-polluted soils, bulk densities differed significantly (P $\leq$ 0.05) (Table 2). Even among crude oil polluted soils significant ( $\leq \leq 0.05)$ exist. Similar findings were observed on the soil bulk densities of non-polluted soils (Table 3). However, value of soil bulk density in crude oil polluted soils varied from $1.43 \mathrm{MgM}^{-3}$ (minimum) at Ogbogene to $1.55 \mathrm{MgM}^{-3}$ (maximum) at Ebocha. (Table 2). In contrast to this, values of soil bulk density ranged from 1.27 to $1.41 \mathrm{MgM}^{-3}$ at Idu and Ebocha, respectively (Table 2). Generally, bulk density values in nondegraded soils are ideal for agronomic usages. Onweremadu and Aunigbo (2007) reported soil bulk density values were higher in crude oil spilled soils of some location in Southeastern Nigeria, while Oyem and Oyem (2013) reported higher values of bulk density in crude oil spilled sites studied and observed that the difference was significant of chosen level of probability Obagi et al (2017) reported values ranged from 1.40 to $1.68 \mathrm{MgM}^{-3}$ in Ahoada area of Rivers State, which is less than critical limit of 1.75 to $5 \mathrm{MgM}^{-3}$ (Soil Survey Staff, 1996). Soil bulk density depends on the type and nature of the soil mineral content as well as organic constituents of given soil (Obi, 2003) especially as it concerns packing pattern.

Total porosity has an inverse relationship with bulk density of soils. Table 3 shows total porosity values against locations where soil samples were collected. Values ranged from $39.4 \%$ to (minimum) at Isukwa to $48.4 \%$ (maximum) at Idu. There was a significant $(\mathrm{P} \leq 0.05)$ in variation in total porosity of Isukwa soils when compared with the rest of the locations (Table 3). Only two levels of variation were encountered in total porosity hence of all the attributes studied, it showed greater uniformity or homogeneity in distribution. Status of total porosity changed when degradation was considered as Table 2 indicated higher and significant $(\mathrm{P} \leq 0.05)$ levels of difference among degraded sites, and between crude oil degraded sites and non-degraded soils. Highest value of total porosity (51.9\%) was obtained in non-degraded soils of Aggah, followed by $51.2 \%$ in non-degraded oils of Utuechi, then $50.3 \%$ to non-degraded soils of 0 bagi, $49.6 \%$ in ondegraded soils of Obie (Table 2).on the other hand, least value of total porosity was found in crude oil degraded soils of Utuechi (29.1\%) (Table 2). Generally, crude oil degradation had a significant effect in reducing total porosity of soils. Oyem and Oyem (2013) had earlier reported that crude oil fills the pore spaces reducing number of oil-free pores. However, results similar to the findings of Obi (2003) who reported total porosity values of 39.1 to $56.0 \%$ in wetland soils of Nigeria. Total porosity of soils usually lies between $70 \%$ to $70 \%$ and used as general indicator of the degree of compaction in a soil (Landon 2011) as a total space less than $40 \%$ is likely to restrict root growth due to excessive strength (Harrod, 1975).

\section{Permeability}

There were significant $(\mathrm{P} \leq 0.05)$ variation in spatial variation of permeability (Table 4$)$. There were seven classes of variation, namely $a, a b, b, b c, b c d, c d$, and d values of permeability range from 0.01 to $2.70 c$, hr ${ }^{-1}$ (Table 4). Generally, permeability differed significantly ( $\mathrm{P} \leq 0.05$ ) between crude oil degraded and non-degraded sampled sites (Table 4). Values of permeability were generally lower in crude oil degraded sites, varying among themselves; and ranging from - 0.15 to $1.89 \mathrm{~cm} \mathrm{hr}^{-1}$ (Table 2). Likewise, there were significant $(\mathrm{P} \leq 0.05)$ in the distribution of permeability in non-degraded soils, indicating that crude oil spillage and possibly any other pollutant may not be the only source and causative agent of variation in a soil system. In non-degraded soils, permeability values ranged from -0.18 to $3.54 \mathrm{~cm} \mathrm{hr}^{-1}$ for minimum and maximum values in Idu and Obrikom, respectively. Suitability for irrigation, practicality of irrigation and profitability of irrigation depend on permeability of soils hence Huden (1983) used it as an important criterion for conducting land capability classification, stressing permeability of upper subsoil. Lower values of permeability in crude oil degraded sites (Table 2) were similar to results from studies Akinwumi et al, 2014) that permeability of soil decreased with increase in crude oil content of soils.

In addition to being a criterion for irrigability of soils (Hudson 1983), Mittal and Shukla (2012), reported that insitu determination of soil permeability is useful to petroleum industries to enable them compute yield capacity of crude oil from the ground. Although, Snakin et al (1996) stated that permeability values of less than $1.25 \mathrm{~cm} \mathrm{hr}^{-1}, 1.25$ to $5 \mathrm{~cm} \mathrm{hr}^{-1}, 5$ to $10 \mathrm{~cm} \mathrm{hr}^{-1}$ and greater than $20 \mathrm{~cm} \mathrm{hr}^{-1}$ represent more to slight degradation, moderately degraded, highly degraded and very highly degraded soils, respectively. Given the above, soils of Aggah, Igwe, Ebocha, Obiofu, Obiozimini, Obrikom and Utuechi (Table 2) were slightly degraded while soils of Idu, Isukwa, Obagi, Ogbogene and Omoku were moderately degraded for optimum crop production.

Permeability index differed significantly ( $\mathrm{P} \leq 0.05$ ), and ranged from 1.55 (minimum) to 2.93 (maximum) in soils of Utuechi and Obagi, respectively. Only soils of Utuechi are outstandingly different from 12 other locations solve (Table 2) in value of permeability index. Status of degradation influenced values of permeability index as shown on Table 2 . More classes of variation in permeability index occurred due to crude oil degradation. Generally, crude oil degradation reduced values of permeability index as values in soils ranged from 0.85 in Agwe and Ogbogene to 2.35 in Utuechi while in nonpolluted soils, permeability index increased from 2.25 to 3.86 in Idu and Obrikom, respectively (Table 4)

\section{References}

i. Akamigbo, F. O. B (2001). Survey, classification and land use of wet-land soils in Nigeria. An invited paper presented at the $2^{\text {th }}$ Annual Conference of Soil distance society Nigeria. November $5^{\text {th }}-9^{\text {th }}$ 2001. University of Calabar, Nigeria.

ii. Akamigbo, F. O. R and Jidere, C. M. (Abosede, E. E. (2013). Effect of crude oil pollution on some soil physical properties. 105R J. Agric. And Vet. Sci. 6(3): 14-17. 
iii. Akunwumi, I. I., Diwa, D. and Ohianigwe, N. (2014). Effects of crude oil contamination on the index of properties, strength and permeability of latentic clay. Int. J. Appl. Sci and Eng. Res. 3(4):631-636.

iv. Blake, G. R and Hartge, K. H (1986). Bulk density in Klute, A (ed) methods of soil analysis Part 1, 9. ASA, Madison, Wisconsin $362-382$

v. Carter, M. R; Gregorich, E. G., Anger, D. A., Beare, M. H., Sparling, G. P; Wardle D. A. and Voroney, R. P. (1999). Interpretation of microbial biomass measurements for soil quality assessment in humid temperate regions. Canadan Journal of Soil Science 79: 507 -520.

vi. Cater, M. R; Gregorich, E. G. Anderson, D. W. Doran, J. W; Jansen, H. H. and Pierch, F. J. (1997). Concepts of soil quality and their significance.

vii. FAO (1976): A framework for Land evaluation. FAO soils Bul. 32. FAO/UNESCO, France

viii. FAO (1979). A provisional methodology for soil Degradation Assessment, FAO Rome pp. 84

ix. FAO (1979): Soils Survey Investigation. FAO. Soil Bull. No 42

X. FAO (Food and Agriculture Organization) (1974). Soil map of the world. Vol. 1, legend Paris.

xi. FAO (Food and Agriculture Organization) (1979). Soil energy investigation for irrigation. Soils bulletin No. 42, FAO, Rome. $177 p p$.

xii. Gee, G. W. and Or, D (2002). Particle size analysis in: Dane, J. H and Tope, G. C. (ed). Methods of soil analysis, part 4. Physical methods SSSA Book Series. No 5. ASA and SSS A Madison WI pp 255 - 293

xiii. Harrod, N. F. (1975). Field experience on light soils. In: Soil Physical Conditions and Crop Production. MAFF Tech. Bull 29, IMSG London pp. 22-51.

xiv. Hortsfall, M and Spitt, A. (2011). Principle of Environmental pollution (with physical, chemical and biological emphasis): $1^{\text {st }}$ ed Published and printed by Metro Prints Ltd. Port Harcourt, Nigeria.

xV. Landon, J.R. (1991). Booker tropical soil manual: A handbook for soil survey and agricultural land evaluation in the tropics and subtropics. Longman scientific \& Technical, Booker Tate Ltd, Thame Oxon, England. 474

xvi. Obi, M. E. (2003). Physical properties: A review of situation within and outside Nigeria. In: Wetland Soils of Nigeria Status of knowledge and potentials. Ojanuga, A. G., Okusami, T. A. and Lekwa, G. (eds) Monogr. No. 2, second edition Soil Sci. Soc. Nigeria. Delar business centre and computer services, Ibadan. Pp. 24-41.

xvii. Obasi, S.N., Nnabuihe, E.C., Manuemelula, N.U. and Ngoh, O.B. (2017). Physical and chemical characteristics of soils affected by oil spillage in Ihugbogo community, Ahoada East, southern Nigeria. Int. J. Adv. Acad. Res. Sci. \& Tech. $8(3): 42$

xviii. Onweremadu, E. U. Okuwa, J. A., Njoku, J. O. and Ufot, U. O. (2011). Soil nitrogen forms dietrovition in isotyperthermic Kaudiudults of central Southeastern Nigeria. Niger. J. Agric. Food and Environ. 7(2): 52-56.

xix. Onweremadu, E. U., Okon, M. A., Ihem E. E., Okuwa, J., Udoh B. T. and Imadejemu, P. (2011). Soil exchangeable calcium mapping in central Southeastern Nigeria using Geographic Information Systems. Niger J. Agric, Food and Environment. 7(2):24-20.

xx. Ogbani P. I., Efiong, G. S., Obi, J. C. and Ibia, T. O. (2011). Characteristics, Potentials and Constraints of Wtland Soils for agricultural development in Akwa Ibom State, Southeastern Nigeria. Niger J. Agric Food and Environ. 7(2):8087.

xxi. Oyem, I. and Lawrence, I. (2013). Effect of crude oil spillage on soil physico-chemical properties in Ugborodo community. Int. J. modern Engineering Res. (IJMER): 3: 3336-3337

xxii. Hudeon, N. W. (1983). Field engineering for agricultural development. Oxford Uni. Press, New York 225 pp.

xxiii. Mittal S. and Shuwa, J. P. (2012). Soil testing for engineers 6 $6^{\text {th }}$ edition. Khanna Publishers. New Delhi pp. $239-245$.

xxiv. Sparks, D. L. (1996). Methods of Soils Analysis. Part 3 Chemical Methods. SSSA and ASA. Madison. Wl pp 551 - 574.

xxv. Soil Survey Staff (1996). Soil survey laboratory methods manual. Soil Survey Investigation Report No. 42 Version 3.0.115. Gov. Printing Office, Washington DC.

\begin{tabular}{|c|c|c|c|c|c|c|}
\hline Location & CS & FS & TS & Si & CL & SiC \\
\hline Aggah & $200.8 \mathrm{de}$ & $325.2 \mathrm{c}$ & $514.1 \mathrm{c}$ & $194.4 \mathrm{def}$ & $303.8 \mathrm{c}$ & $1.10 \mathrm{~b}$ \\
\hline Agwe & $130.6 \mathrm{~g}$ & $235.9 \mathrm{e}$ & $380.6 \mathrm{~g}$ & $168.1 \mathrm{f}$ & $490.4 \mathrm{a}$ & $0.53 \mathrm{~b}$ \\
\hline Ebocha & $134.1 \mathrm{~g}$ & $211.7 \mathrm{~g}$ & $347.2 \mathrm{~h}$ & $132.4 \mathrm{~g}$ & $506.0 \mathrm{a}$ & $0.47 \mathrm{~b}$ \\
\hline Idu & $222.0 \mathrm{~cd}$ & $385.6 \mathrm{a}$ & $628.8 \mathrm{a}$ & $236.3 \mathrm{~d}$ & $140.5 \mathrm{gh}$ & $1.91 \mathrm{~b}$ \\
\hline Isuka & $227.5 \mathrm{bcd}$ & $208.5 \mathrm{~g}$ & $440.8 \mathrm{f}$ & $307.8 \mathrm{c}$ & $263.8 \mathrm{~d}$ & $1.61 \mathrm{~b}$ \\
\hline Obagi & $279.6 \mathrm{a}$ & $211.8 \mathrm{~g}$ & $495.4 \mathrm{cde}$ & $207.1 \mathrm{de}$ & $274.9 \mathrm{~cd}$ & $0.99 \mathrm{~b}$ \\
\hline Obie & $221.2 \mathrm{~cd}$ & $254.9 \mathrm{~d}$ & $481.2 \mathrm{e}$ & $412.2 \mathrm{a}$ & $113.2 \mathrm{hi}$ & $3.64 \mathrm{~b}$ \\
\hline Obiofu & $153.7 \mathrm{fg}$ & $237.4 \mathrm{e}$ & $396.2 \mathrm{~g}$ & $193.8 \mathrm{ef}$ & $419.0 \mathrm{~b}$ & $0.45 \mathrm{~b}$ \\
\hline Obiozimini & $191.4 \mathrm{e}$ & $268.8 \mathrm{~d}$ & $488.1 \mathrm{de}$ & $412.4 \mathrm{a}$ & $107.4 \mathrm{i}$ & $3.79 \mathrm{~b}$ \\
\hline Obrikou & $232.1 \mathrm{bc}$ & $221.9 \mathrm{fg}$ & $458.0 \mathrm{f}$ & $320.9 \mathrm{c}$ & $223.5 \mathrm{e}$ & $1.66 \mathrm{~b}$ \\
\hline Ogbogene & $220.2 \mathrm{~cd}$ & $364.9 \mathrm{~b}$ & $590.0 \mathrm{~b}$ & $232.8 \mathrm{de}$ & $161.9 \mathrm{fg}$ & $1.70 \mathrm{~b}$ \\
\hline Omoku & $253.4 \mathrm{~b}$ & $229.4 \mathrm{ef}$ & $481.6 \mathrm{e}$ & $333.1 \mathrm{bc}$ & $184.5 \mathrm{f}$ & $2.13 \mathrm{~b}$ \\
\hline Utuechi & $164.9 \mathrm{f}$ & $332.9 \mathrm{c}$ & $503.0 \mathrm{~cd}$ & $369.1 \mathrm{~b}$ & $91.7 \mathrm{i}$ & $55.89 \mathrm{a}$ \\
\hline
\end{tabular}

Table 1: Particle Size Distribution of Soils by Location 


\begin{tabular}{|c|c|c|c|c|c|c|c|}
\hline Status & Location & CS & FS & TS & $\mathbf{S i}$ & $\mathbf{C L}$ & SiC \\
\hline COP & Aggah & $195.0 \mathrm{cde}$ & $315.2 \mathrm{~d}$ & $481.6 \mathrm{efgh}$ & $197.8 \mathrm{cdef}$ & $330.6 \mathrm{e}$ & $1.04 \mathrm{~b}$ \\
\hline COP & Agwe & $113.7 \mathrm{~g}$ & 230.9 hij & $374.1 \mathrm{l}$ & $156.6 \mathrm{efg}$ & $469.4 \mathrm{bc}$ & $0.52 \mathrm{~b}$ \\
\hline COP & Ebocha & $131.5 \mathrm{fg}$ & 196.61 & $332.0 \mathrm{~m}$ & $144.6 \mathrm{fg}$ & $513.9 \mathrm{a}$ & $0.51 \mathrm{~b}$ \\
\hline COP & Idu & $220.0 \mathrm{bc}$ & $378.5 \mathrm{ab}$ & $636.6 \mathrm{a}$ & $244.4 \mathrm{c}$ & $128.9 \mathrm{~lm}$ & $2.32 \mathrm{~b}$ \\
\hline COP & Isuka & 226.7 bc & $208.5 \mathrm{kl}$ & $440.0 \mathrm{~J}$ & $306.1 \mathrm{~b}$ & $263.9 \mathrm{gh}$ & $1.59 \mathrm{~b}$ \\
\hline COP & Obagi & $275.2 \mathrm{a}$ & $208.1 \mathrm{kl}$ & $487.3 \mathrm{efg}$ & 202.1 cde & 313.7 ef & $0.87 \mathrm{~b}$ \\
\hline COP & Obie & 228.7 bc & $256.2 \mathrm{ef}$ & 490.0 efg & $406.6 \mathrm{a}$ & $110.5 \mathrm{lmn}$ & $3.66 \mathrm{~b}$ \\
\hline COP & Obiofu & $148.7 \mathrm{fg}$ & 233.7 ghij & $387.5 \mathrm{kl}$ & $190.3 \mathrm{cdef}$ & $429.2 \mathrm{~cd}$ & $0.43 \mathrm{~b}$ \\
\hline COP & Obiozimini & $165.2 \mathrm{ef}$ & $267.4 \mathrm{e}$ & 485.0 efg & $416.6 \mathrm{a}$ & $105.5 \mathrm{mn}$ & $3.76 \mathrm{~b}$ \\
\hline COP & Obrikom & $227.7 \mathrm{bc}$ & $218.3 \mathrm{ijk}$ & $450.0 \mathrm{hij}$ & $310.9 \mathrm{~b}$ & 242.2 ghi & $1.49 \mathrm{~b}$ \\
\hline COP & Ogbogene & 213.7 bc & $371.2 \mathrm{~b}$ & $590.0 \mathrm{c}$ & $227.8 \mathrm{~cd}$ & $136.7 \mathrm{~lm}$ & $1.63 \mathrm{~b}$ \\
\hline COP & Omoku & $232.4 \mathrm{bc}$ & 222.9 hijk & $454.1 \mathrm{hij}$ & $321.6 \mathrm{~b}$ & 224.4 hij & $1.69 \mathrm{~b}$ \\
\hline COP & Utuechi & $167.4 \mathrm{def}$ & $328.7 \mathrm{~d}$ & $501.2 \mathrm{Ef}$ & $312.8 \mathrm{~b}$ & $102.2 \mathrm{mn}$ & $106.28 \mathrm{a}$ \\
\hline NP & Aggah & $206.7 \mathrm{bcd}$ & $335.2 \mathrm{~cd}$ & $546.6 \mathrm{~d}$ & 191.1 cdef & $277.0 \mathrm{fg}$ & $1.15 \mathrm{~b}$ \\
\hline NP & Agwe & $147.4 \mathrm{f}$ & $240.9 \mathrm{fgh}$ & $387.1 \mathrm{kl}$ & 179.6 def & $511.3 \mathrm{a}$ & $0.53 \mathrm{~b}$ \\
\hline NP & Ebocha & $136.6 \mathrm{fg}$ & 226.9 hijk & $362.3 \mathrm{l}$ & $120.2 \mathrm{~g}$ & $498.1 \mathrm{ab}$ & $0.42 \mathrm{~b}$ \\
\hline NP & Idu & $224.1 \mathrm{bc}$ & $392.7 \mathrm{a}$ & $620.9 \mathrm{Ab}$ & $228.1 \mathrm{~cd}$ & $152.1 \mathrm{kl}$ & $1.50 \mathrm{~b}$ \\
\hline NP & Isuka & $228.3 \mathrm{bc}$ & $208.5 \mathrm{kl}$ & $441.6 \mathrm{Ij}$ & $309.4 \mathrm{~b}$ & $263.7 \mathrm{gh}$ & $1.63 \mathrm{~b}$ \\
\hline NP & Obagi & $284.0 \mathrm{a}$ & $215.6 \mathrm{jkl}$ & $503.5 \mathrm{e}$ & $212.1 \mathrm{~cd}$ & 236.0 ghi & $1.11 \mathrm{~b}$ \\
\hline NP & Obie & $213.7 \mathrm{bc}$ & 253.7 efg & 472.5 fghi & $417.8 \mathrm{a}$ & $115.9 \mathrm{lmn}$ & $3.63 \mathrm{~b}$ \\
\hline NP & Obiofu & 158.7 ef & $241.2 \mathrm{fgh}$ & $405.0 \mathrm{k}$ & $197.3 \mathrm{cdef}$ & $408.9 \mathrm{~d}$ & $0.47 \mathrm{~b}$ \\
\hline NP & Obiozimini & 217.6 bc & $270.1 \mathrm{e}$ & $491.2 \mathrm{efg}$ & $408.3 \mathrm{a}$ & $109.4 \mathrm{mn}$ & $3.82 \mathrm{~b}$ \\
\hline NP & Obrikou & $236.5 \mathrm{~b}$ & 225.6 hijk & 466.0 ghij & $330.9 \mathrm{~b}$ & $204.8 \mathrm{ij}$ & $1.83 \mathrm{~b}$ \\
\hline NP & Ogbogene & $226.7 \mathrm{bc}$ & $358.5 \mathrm{bc}$ & $590.0 \mathrm{bc}$ & $237.8 \mathrm{c}$ & $187.0 \mathrm{jk}$ & $1.77 \mathrm{~b}$ \\
\hline NP & Omoku & $274.4 \mathrm{a}$ & 235.9 ghi & $509.1 \mathrm{e}$ & $344.6 \mathrm{~b}$ & $144.5 \mathrm{klm}$ & $2.58 \mathrm{~b}$ \\
\hline NP & Utuechi & $162.4 \mathrm{ef}$ & $337.2 \mathrm{~cd}$ & $504.7 \mathrm{e}$ & $425.3 \mathrm{a}$ & $81.1 \mathrm{n}$ & $5.51 \mathrm{~b}$ \\
\hline
\end{tabular}

Table 2: Particle Size Distribution of Soils by Status and Location

\begin{tabular}{|c|c|c|c|c|}
\hline Location & BD & TP & $\begin{array}{c}\text { Permeability } \\
\text { (cm/hr) }\end{array}$ & $\begin{array}{c}\text { Permeability } \\
\text { index }\end{array}$ \\
\hline Aggah & $1.44 \mathrm{abcd}$ & $45.7 \mathrm{a}$ & $1.22 \mathrm{bc}$ & $2.46 \mathrm{ab}$ \\
Agwe & $1.46 \mathrm{ab}$ & $46.0 \mathrm{a}$ & $1.22 \mathrm{bc}$ & $2.21 \mathrm{~b}$ \\
Ebocha & $1.48 \mathrm{a}$ & $45.7 \mathrm{a}$ & $1.20 \mathrm{bc}$ & $2.22 \mathrm{~b}$ \\
Idu & $1.38 \mathrm{e}$ & $48.4 \mathrm{a}$ & $1.95 \mathrm{ab}$ & $2.90 \mathrm{a}$ \\
Isuka & $1.41 \mathrm{cde}$ & $39.4 \mathrm{~b}$ & $1.87 \mathrm{ab}$ & $2.62 \mathrm{ab}$ \\
Obagi & $1.39 \mathrm{e}$ & $48.1 \mathrm{a}$ & $1.68 \mathrm{~b}$ & $2.93 \mathrm{a}$ \\
Obie & $1.45 \mathrm{ab}$ & $45.5 \mathrm{a}$ & $1.26 \mathrm{bc}$ & $2.42 \mathrm{ab}$ \\
Obiofu & $1.45 \mathrm{ab}$ & $45.6 \mathrm{a}$ & $0.40 \mathrm{~cd}$ & $2.17 \mathrm{~b}$ \\
Obiozimini & $1.41 \mathrm{de}$ & $47.0 \mathrm{a}$ & $0.88 \mathrm{bcd}$ & $2.26 \mathrm{~b}$ \\
Obrikom & $1.44 \mathrm{bcd}$ & $46.6 \mathrm{a}$ & $1.10 \mathrm{bc}$ & $2.55 \mathrm{ab}$ \\
Ogbogene & $1.40 \mathrm{e}$ & $47.5 \mathrm{a}$ & $1.30 \mathrm{bc}$ & $2.69 \mathrm{ab}$ \\
Omoku & $1.41 \mathrm{cde}$ & $47.5 \mathrm{a}$ & $2.70 \mathrm{a}$ & $2.91 \mathrm{a}$ \\
Utuechi & $1.44 \mathrm{abc}$ & $45.7 \mathrm{a}$ & $-0.01 \mathrm{~d}$ & $1.55 \mathrm{c}$ \\
\hline
\end{tabular}

Table 3: Soil Bulk Density and Permeability Characteristics by Location 


\begin{tabular}{|c|c|c|c|c|c|}
\hline Status & Location & BD & TP & $\begin{array}{c}\text { Permeability } \\
(\mathrm{cm} / \mathrm{hr})\end{array}$ & Permeability index \\
\hline $\mathrm{COP}$ & Ebocha & $1.55 a$ & 43.3defg & 0.72cdefghij & 2.06efgh \\
\hline $\mathrm{COP}$ & Obiofu & $1.54 \mathrm{ab}$ & $43.7 \mathrm{dfg}$ & $0.09 \mathrm{Ij}$ & $1.44 \mathrm{hij}$ \\
\hline $\mathrm{COP}$ & Agwe & $1.53 \mathrm{abc}$ & $41.8 \mathrm{~g}$ & $-0.15 \mathrm{Ij}$ & 0.85J \\
\hline $\mathrm{COP}$ & Obie & 1.52abcd & 45.0abcdfg & 0.55defghij & 2.06efgh \\
\hline $\mathrm{COP}$ & Utuechi & 1.52abcd & 29.1h & 0.19egijk & 1.39hij \\
\hline $\mathrm{COP}$ & Aggah & $1.51 \mathrm{abcd}$ & 45.1bcdfg & $0.54 \mathrm{efghij}$ & $2.35 \mathrm{defg}$ \\
\hline $\mathrm{COP}$ & Obrikou & $1.50 \mathrm{bcd}$ & $43.2 \mathrm{dfg}$ & $0.15 \mathrm{Ij}$ & $1.10 \mathrm{ij}$ \\
\hline $\mathrm{COP}$ & Idu & $1.50 \mathrm{bcd}$ & $42.1 \mathrm{fg}$ & $0.21 \mathrm{fgijk}$ & $1.10 \mathrm{ij}$ \\
\hline COP & Omoku & $1.49 \mathrm{~d}$ & $45.0 \mathrm{bcdfg}$ & $0.20 \mathrm{gijk}$ & 1.60ghij \\
\hline COP & Obiozimini & $1.48 \mathrm{~cd}$ & $44.3 \mathrm{cdfg}$ & $-0.04 \mathrm{Ij}$ & 1.60ghij \\
\hline $\mathrm{COP}$ & Isuka & $1.48 \mathrm{cde}$ & 46.3abcdfg & 0.29fgijk & $1.85 \mathrm{ghi}$ \\
\hline $\mathrm{COP}$ & Obagi & $1.47 \mathrm{de}$ & $44.7 \mathrm{cdfg}$ & 1.89abcdeh & $2.04 \mathrm{fgh}$ \\
\hline COP & Ogbogene & $1.43 \mathrm{ef}$ & $43.2 \mathrm{dfg}$ & $0.16 \mathrm{Ij}$ & 0.85J \\
\hline NP & Ebocha & $1.41 \mathrm{fg}$ & 48.2abcdfg & 1.73bcdefghi & $2.86 \mathrm{cdef}$ \\
\hline NP & Agwe & $1.39 \mathrm{fgh}$ & 48.4abcdf & 2.35abcde & $2.99 \mathrm{bcd}$ \\
\hline NP & Obie & 1.39fgh & 49.6abce & $2.56 \mathrm{abcd}$ & $3.59 \mathrm{abc}$ \\
\hline NP & Aggah & 1.38fghi & $51.9 a$ & $3.34 \mathrm{ab}$ & $3.74 \mathrm{ab}$ \\
\hline NP & Obrikou & $1.37 \mathrm{ghi}$ & 49.6abcd & $3.54 a$ & $3.86 a$ \\
\hline NP & Utuechi & $1.37 \mathrm{ghi}$ & $51.2 \mathrm{ab}$ & $2.81 \mathrm{abc}$ & $3.50 \mathrm{abc}$ \\
\hline NP & Ogbogene & 1.36ghij & 47.8abcdfg & 2.38abcde & $3.75 \mathrm{ab}$ \\
\hline NP & Obiofu & 1.36ghij & 49.0abcd & 0.59hijk & $3.25 \mathrm{abc}$ \\
\hline NP & Isuka & 1.34hij & 49.1abcd & 1.56cdefghi & $2.92 \mathrm{cde}$ \\
\hline NP & Obiozimini & $1.34 \mathrm{hij}$ & 49.0abcd & 2.24abcdef & $3.50 \mathrm{abc}$ \\
\hline NP & Omoku & $1.33 \mathrm{ij}$ & 48.7abcdfg & 2.31abcdefg & $3.52 \mathrm{abc}$ \\
\hline NP & Obagi & $1.31 \mathrm{jk}$ & $50.3 \mathrm{abc}$ & $3.51 \mathrm{a}$ & 3.79a \\
\hline NP & Idu & $1.27 \mathrm{k}$ & 48.3abcdfg & $-0.18 \mathrm{~J}$ & $2.25 \mathrm{defgh}$ \\
\hline
\end{tabular}

Table 4: Soil Bulk Density and Permeability Characteristics by Status and Location 